\title{
Plasma protein oxidation and its correlation with antioxidant potential during human aging
}

\author{
Kanti Bhooshan Pandey, Mohd Murtaza Mehdi, Pawan Kumar Maurya and Syed Ibrahim Rizvi* \\ Department of Biochemistry, University of Allahabad, Allahabad, India
}

\begin{abstract}
Previous studies have indicated that the main molecular characteristic of aging is the progressive accumulation of oxidative damages in cellular macromolecules. Proteins are one of the main molecular targets of age-related oxidative stress, which have been observed during aging process in cellular systems.. Reactive oxygen species (ROS) can lead to oxidation of amino acid side chains, formation of protein-protein cross-linkages, and oxidation of the peptide backbones. In the present study, we report the age-dependent oxidative alterations in biomarkers of plasma protein oxidation: protein carbonyls (PCO), advanced oxidation protein products (AOPPs) and plasma total thiol groups (T-SH) in the Indian population and also correlate these parameters with total plasma antioxidant potential. We show an age dependent decrease in T-SH levels and increase in PCO and AOPPs level. The alterations in the levels of these parameters correlated significantly with the total antioxidant capacity of the plasma. The levels of oxidized proteins in plasma provide an excellent biomarker of oxidative stress due to the relative long half-life of such oxidized proteins.
\end{abstract}

Keywords: Human aging, oxidative stress, AOPPs, protein carbonyls, -SH

\section{Introduction}

Oxidative damage due to impaired redox homeostasis is involved in aging and age-related diseases [1,2]. Reactive oxygen species (ROS) are generated as byproduct of aerobic metabolism and exposure to various natural as well as synthetic toxicants. A certain amount of oxidative stress takes place even under normal cellular conditions; however, the rate of this damage increases during the aging as the efficiency of redox regulation decreases $[3,4]$. ROS may damage all types of biological molecules including proteins and lipids in plasma of aged subjects $[5,6]$.

Proteins are especially vulnerable to oxidative stress; the attack of ROS against proteins modifies amino acids: lysine, arginine, proline, and histidine residues generating carbonyl moieties, which has been identified as an early marker for oxidative protein damage and is used as a measure of oxidative protein dam-

${ }^{*}$ Corresponding author: Dr. Syed Ibrahim Rizvi, Department of Biochemistry, University of Allahabad, Allahabad, 211002, India. Tel.: +91 9415305910; E-mail: sirizvi@gmail.com. age [7]. Besides, the use of protein carbonyls (PCO) as index of oxidative stress has some advantages in comparison with the measurement of other oxidation products because of the early formation and the relative stability of carbonylated proteins [8]. Action of chloraminated oxidants, mainly hypochlorous acid and chloramines, produced by myeloperoxidase in activated neutrophils, forms dityrosine containing crosslinked protein products known as advanced oxidation protein products (AOPPs) and are considered as reliable markers of the degree of oxidative modifications of proteins [9]. Plasma total thiol groups (T-SH) is a good reflection of excess free radical generation, since the conformation of albumin is altered, allowing -SH groups to be oxidized [10].

The presence of correlation between antioxidant capacity of the plasma and oxidative protein damage during aging has been reported in several tissues in different strains of rat [5,6]; however, data on changes of oxidative stress markers in plasma and erythrocytes of healthy populations during aging are few and sometimes contradictory $[11,12]$. Recently, a significant age-dependent decline in plasma antioxidant capacity, measured in terms of ferric reducing ability of the 
plasma (FRAP) values, has reported from our lab [13]. Since the antioxidant capacity of the plasma is mainly related to dietary intake of antioxidants [14], it is important to study the correlation between antioxidant capacity of plasma and the markers of oxidative stress in different populations. The present study reports age dependent oxidative alterations in plasma protein measured in terms of plasma protein carbonyls (PCO), AOPPs and T-SH in Indian population. Our aim was to determine possible correlation among these parameters with total plasma antioxidant potential measured in terms of FRAP values.

\section{Materials and methods}

The study was carried out on 80 normal healthy subjects of both sexes (61 males and 19 females) between the ages of 18 and 85 years, the selection criteria has been described earlier $[4,13,15]$. The BMI of the subjects ranged from 18.8 to $26.2 \mathrm{Kg} / \mathrm{m}^{2}$. All volunteers were screened for asthma, tuberculosis, diabetes mellitus or any other major illness. None of the subjects were smokers or were taking any medication. Care was also taken to exclude the volunteers taking/have taken the any nutritional supplements since last three months. The elderly subjects were living at home but functionally independent without any cognitive impairment. All persons gave their informed consent for the use of their blood samples for the study. Venous blood was obtained at fasting condition in the morning by venipuncture in sterile polystyrene tubes containing heparin. Plasma was obtained by centrifuging the blood at $800 \times \mathrm{g}$ for $10 \mathrm{~min}$ at $4^{\circ} \mathrm{C}$. Antioxidant capacity measurements were performed immediately, for further analyses the plasma was frozen and stored at $-80^{\circ} \mathrm{C}$ for not more than $2-3$ days. The protocol of study was in conformity with the guidelines of the Allahabad University Ethical Committee.

\subsection{Determination of plasma protein carbonyls}

Plasma protein carbonyls (PCO) content was measured according to procedure of Levine et al. [7]. Plasma samples were taken in two tubes as test and control. $4.0 \mathrm{ml}$ of $10 \mathrm{mM}$ 2,4-dinitrophenylhydrazine (DNPH) prepared in $2 \mathrm{M} \mathrm{HCl}$ was added to the test sample and $4.0 \mathrm{ml}$ of $2 \mathrm{M} \mathrm{HCl}$, alone was added to the control sample. The contents were mixed thoroughly and incubated for 1 hour in the dark at $37^{\circ} \mathrm{C}$. The tubes were shaken intermittently every 10 minutes to facilitate the reactions with proteins. After that, 20\% TCA (w/v) was added to both tubes and the mixture left in ice for 10 minutes. The tubes were then centrifuged at 3,500 rpm for $20 \mathrm{~min}$ to obtain the protein pellets. The supernatant was carefully aspirated and discarded. The protein pellets were washed three times with ethanol: ethyl acetate $(1: 1, \mathrm{v} / \mathrm{v})$ solution to remove unreacted DNPH and lipid remnants. Finally protein pellets were dissolved in $6 \mathrm{M}$ guanidine hydrochloride and incubated for 10 minutes at $37^{\circ} \mathrm{C}$. The insoluble materials were removed by centrifugation. PCO content was determined by taking the spectra of the supernatant at $370 \mathrm{~nm}$. Each sample was read against the control. The PCO content was calculated by using an absorption coefficient (e) of $22,000 \mathrm{M}^{-1} \mathrm{~cm}^{-1}$ and data was expressed in $\mathrm{nmol} / \mathrm{L}$ of plasma.

\subsection{Determination of plasma AOPPs}

Determination of AOPPs in plasma was based on spectrophotometric detection according to WitkoSarsat et al. [9]. Briefly, $200 \mathrm{ml}$ of plasma (diluted 1:5 with phosphate-buffered saline (PBS)) as test, $200 \mathrm{ml}$ of chloramines-T solution $(0-100 \mu \mathrm{mol} / \mathrm{L})$ for calibration and $200 \mathrm{ml}$ of PBS as blank were applied. $10 \mu \mathrm{l}$ of $1.16 \mathrm{M}$ potassium iodide and $20 \mu \mathrm{l}$ of acetic acid were added and absorbance at $340 \mathrm{~nm}$ was measured immediately. Concentration of AOPPs was expressed as $\mu \mathrm{mol} / \mathrm{L}$ of chloramine-T equivalents.

\subsection{Determination of plasma total thiol content}

Plasma T-SH concentration was estimated as previous [16] based on the ability of the -SH group to reduce 5, 5'-dithiobis, 2-nitrobenzoic acid (DTNB) and form a yellow colored anionic product whose absorbance is measured at $412 \mathrm{~nm}$. The concentration of T-SH is expressed as $\mu \mathrm{mol} / \mathrm{L}$ of plasma.

\subsection{Measurement of antioxidant capacity of plasma}

The antioxidant capacity of human plasma was measured in terms of ferric reducing ability of plasma (FRAP) values, according to method of Benzie and Strain [17]. Briefly working FRAP reagent was prepared by mixing acetate buffer ( $300 \mathrm{mM}$, pH 3.6), 2, 4, 6-tri [2-pyridyl]-s-triazine ( $10 \mathrm{mM}$ in $40 \mathrm{mM} \mathrm{HCl}$ ) solution and $\mathrm{FeCl}_{3} \cdot 6 \mathrm{H}_{2} \mathrm{O}(20 \mathrm{mmol} / \mathrm{L})$ solution in 10:1:1 ratio respectively. $3 \mathrm{ml}$ of FRAP reagent was mixed with $100 \mu \mathrm{L}$ of plasma; the content was mixed vigorously. The absorbance was read at $593 \mathrm{~nm}$ at the 


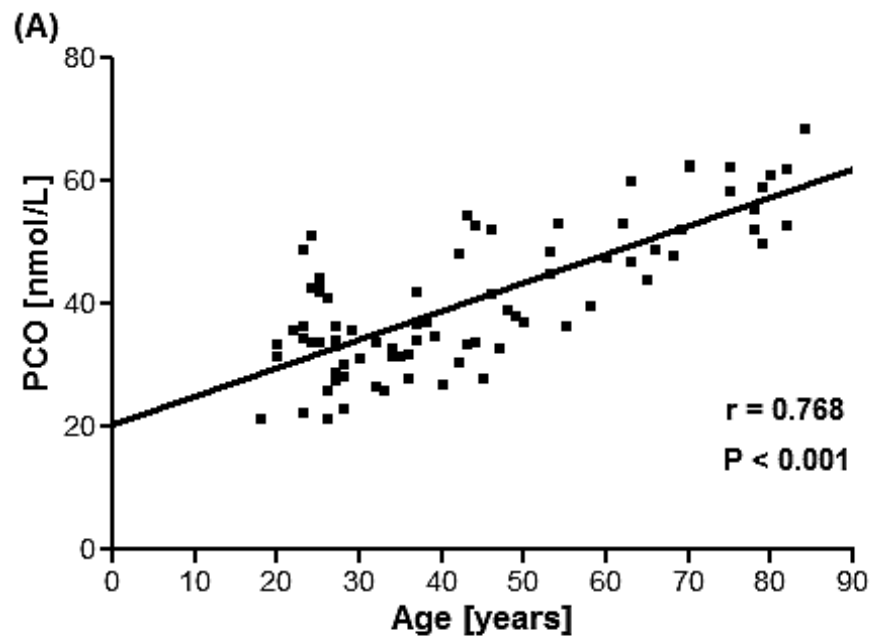

(B)

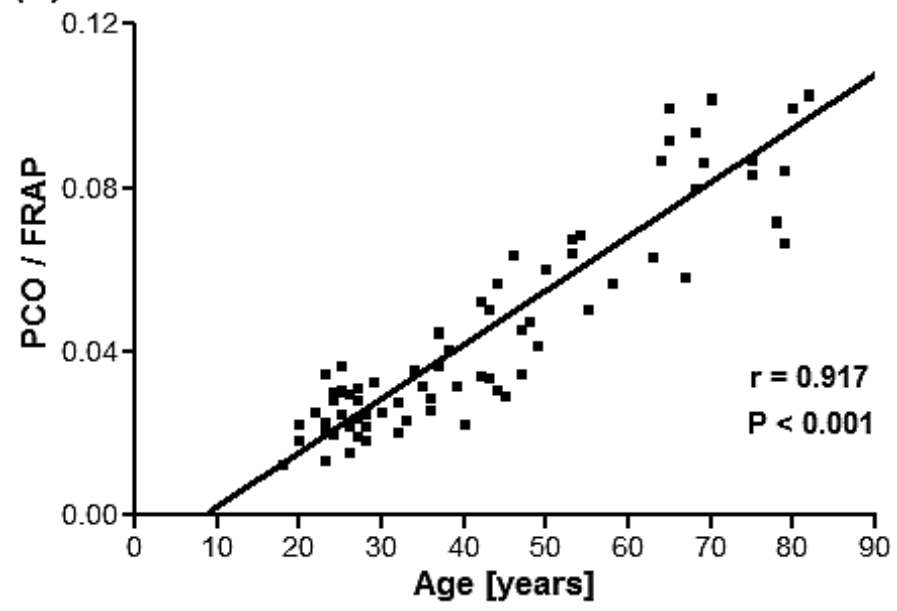

Fig. 1. (A)Plasma protein carbonyls (PCO) content plotted as a function of human age $(n=80)$. The concentration of the PCO is expressed as nmol/L of plasma. (B) Plot of quotient (PCO/FRAP values) as a function of human age. FRAP values expressed as $\mu$ mol Fe (II)/L of plasma.

interval of 30 seconds for 4 minutes. Aqueous solution of known $\mathrm{Fe}^{2+}$ concentration in the range of 100 to $1000 \mu \mathrm{mol} / \mathrm{L}$ was used for calibration. Using the regression equation the FRAP values $(\mu \mathrm{mol} \mathrm{Fe}(\mathrm{II}) / \mathrm{L})$ of the plasma was calculated.

Statistical analyses were performed using the software PRISM 4 (Graphpad Software Inc., San Diego, CA). The relationships among the various parameters were assessed using Pearson correlation coefficient (r) and the values were considered to be significant when $p<0.05$.

\section{Results and discussion}

ROS are one of the primary causes for damage to biomolecules during aging process. Although differ- ent types of molecular damage accumulate at different rates and to different extents in different cells, the fact remains that there is a progressive increase in molecular heterogeneity with age [18]. Erythrocytes are highly susceptible to oxidative damage due to the high cellular concentration of oxyhemoglobin, a potentially powerful promoter for the oxidative processes [19]. In the past several years, oxidative damage to erythrocytes has been intensely studied to explain destructive events in many hematological disorders and in aging $[4,15]$. We observed an age dependent increase in plasma PCO level (Fig. 1A). Figure 1B shows the correlation between PCO and total plasma antioxidant capacity, measured in terms of FRAP values by plotting a quotient of PCO/FRAP as a function of human age. An agedependent decline in total plasma antioxidant capacity (FRAP values) has already been reported from our lab- 

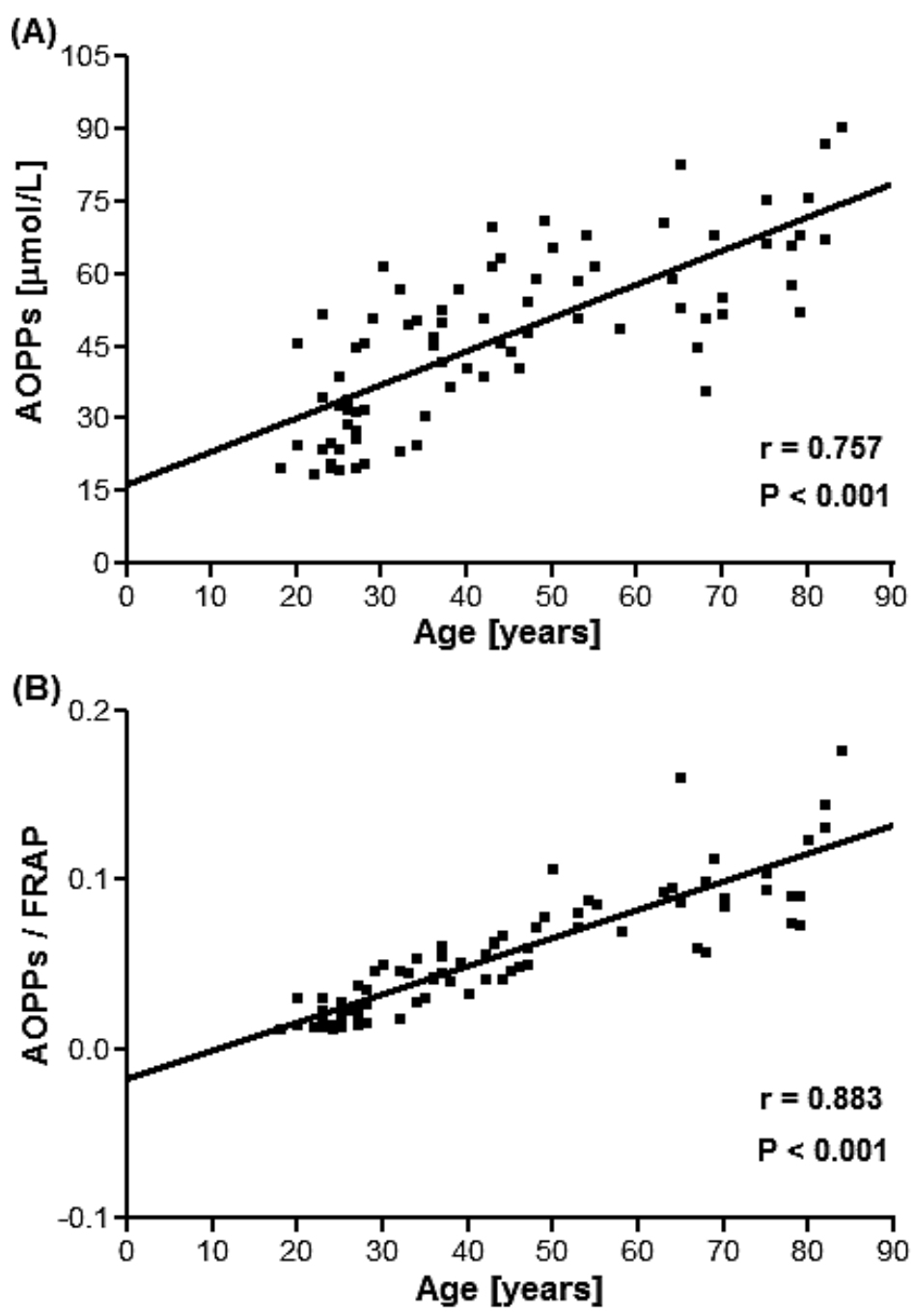

Fig. 2. (A)Plasma advanced oxidation protein products (AOPPs) level plotted as a function of human age $(n=80)$. The concentration of the AOPPs is expressed as $\mu \mathrm{mol} / \mathrm{L}$ of chloramine-T equivalents. (B)Plot of quotient (AOPPs/FRAP values) as a function of human age. FRAP values expressed as $\mu \mathrm{mol} \mathrm{Fe}$ (II)/L of plasma.

oratory [13]. The increase in PCO correlates significantly $(p<0.001)$ with decrease in the antioxidant capacity of the plasma during human aging. Age dependent increase in PCO level is direct evidence towards the fact that oxidative stress increases during aging concomitant with the fall in the antioxidant capacity of the body.

AOPPs are defined as dityrosine-containing crosslinked protein products and are considered as reliable marker to estimate the degree of protein oxidation [9]. Figure 2A shows the age-dependent elevation in plasma AOPPs level. There was a significant positive correlation between elevation in AOPPs and chronological age $(p<0.001)$; this elevation also correlates with the total antioxidant capacity of the plasma (Fig. 2B). Oxidative modification of proteins, considering their multiple functions, unlike lipid peroxidation, can be selective and specific. Biochemical characterization has revealed that AOPPs are carried by plasma proteins, especially albumin [20]. AOPPs can be formed in vitro by exposure of serum albumin to hypochlorous acid (HO$\mathrm{Cl}$ ). Thus, AOPPs might be formed during oxidative stress by reaction of plasma proteins with chlorinated oxidants, and have been considered as novel markers of oxidant-mediated protein damage. Age related increase in plasma AOPPs level signifies increased oxidative stress during aging.

Aging is accompanied by a decrease in the level 

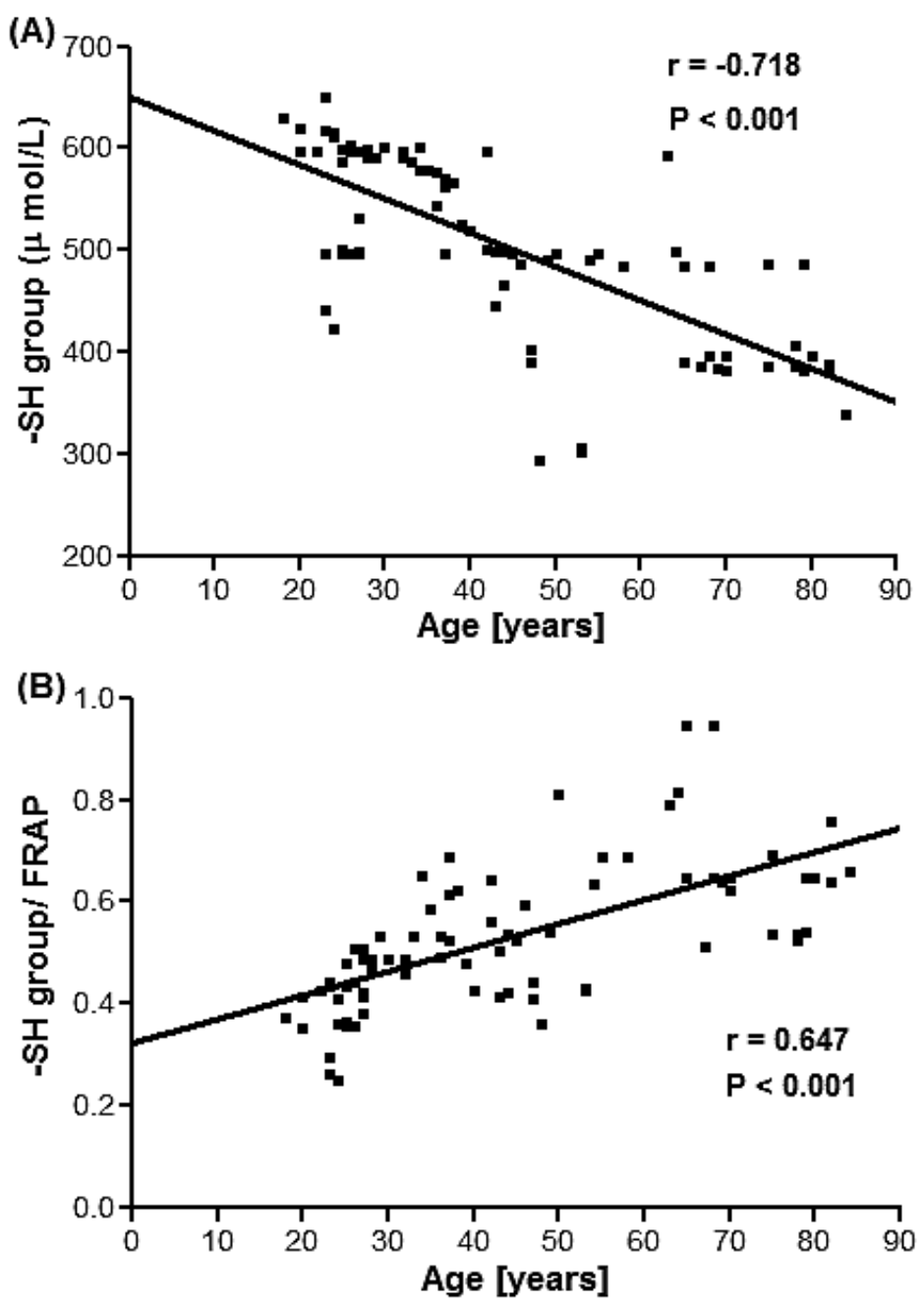

Fig. 3. (A)Plasma -SH group concentration plotted as a function of human age $(n=80)$. The concentration of the SH group is expressed as $\mu \mathrm{mol} / \mathrm{L}$ plasma. (B)Plot of quotient (plasma SH group/FRAP values) as a function of human age. FRAP values expressed as $\mu$ mol Fe (II)/L of plasma.

of the most important antioxidant glutathione (GSH) and of cysteine [21], which can be a result of both an elevated demand and inhibited GSH biosynthesis. -SH groups play a prominent role in antioxidant reactions, and also in reactions of catalysis, regulation, electron transport and those preserving the correct structure of proteins [22].

We observe a significant negative correlation between total plasma T-SH concentration and human age $(p<0.001)$ (Fig. 3). The age-dependent decrease in plasma T-SH concentration also correlates with antioxidant potential of the plasma (Fig. 3B). The levels and mutual relations between different redox forms of thiols in plasma are decisive for the plasma redox capacity, which determines its proper function. For all these reasons, plasma thiols may be considered not only as metabolites transported between organs and tissues, but also as functionally important plasma components [23]. Loss in the level of -SH groups in elderly human plasma indicates an altered redox status as well as reduced capacity to maintain correct structures of the proteins during aging.

Oxidative damage may lead to loss in specific protein function. Since proteins have unique biological functions, there are often unique functional consequences resulting from their modification. Analysis of the proteins provides crucial information in the diagnosis of many disorders including central nervous system diseases [24]. In many inflammatory diseases, changes in main serum proteins have been recently reported [25]. 
Our results on the age dependent increased production of PCO, AOPPs and loss in T-SH content in Indian population and the correlation of these parameters with the generalized decline in total antioxidant capacity of the plasma emphasize that the proteins are vulnerable towards oxidative stress which plays major role in human aging. Although, proteolytic systems exist to remove oxidized proteins, protein oxidation is an excellent biomarker of oxidative stress due to the relative long half-life of such oxidized proteins. Following severe oxidative stress, the decrease in the proteolytic degradation and accumulation of non-folded proteins may be the cause and/or the consequence of many disorders and aging. However the exact relationship among protein oxidation, protein dysfunction, and aging remain largely unclear; further investigations are still required.

\section{Acknowledgements}

Kanti Bhooshan Pandey is a recipient of Senior Research Fellowship from Council of Scientific \& Industrial Research (CSIR) New Delhi, India. Mohd Murtaza Mehdi is a recipient of Junior Research Fellowship from Indian Council of Medical Research, India. S. I. Rizvi acknowledges the financial support from University Grants Commission, New Delhi (MRP 37392/2009 SR).

\section{References}

[1] V.B. Junqueira, S.B. Barros, S.S. Chan, L. Rodrigues, L. Giavarotti, R.L. Abud and G.P. Deucher, Aging and oxidative stress, Mol. Aspects Med 25 (2004), 5-16.

[2] S.I. Rizvi and P.K. Maurya, Alterations in antioxidant enzymes during aging in humans, Mol Biotechnol 37 (2007), 58-61.

[3] L.Gil, W. Siems, B. Mazurek, J. Gross, P. Schroeder, P. Voss and T. Grune, Age associated analysis of oxidative stress parameters in human plasma and erythrocytes, Free Radic Res 40 (2006), 405-505.

[4] S.I. Rizvi and P.K. Maurya, Markers of oxidative stress in erythrocytes during aging in human, Ann N Y Acad Sci 1100 (2007), 373-382.

[5] R. Kayali, U. Cakatay and F. Tekeli, Male rats exhibit higher oxidative protein damage than females of the same chronological age, Mech. Ageing Dev 128 (2007), 365-369.

[6] U. Cakatay, S. Aydin, K. Yanar and H. Uzun, Genderdependent variations in systemic biomarkers of oxidative protein, DNA, and lipid damage in aged rats, Aging Male 13, (2010), 51-58.

[7] R.L. Levine, D, Garland, C.N. Oliver, A. Amici, I. Climent, A.G.Lenz, B.W. Ahn, S. Shaltiel and E.R. Stadtman, Determination of carbonyl content in oxidatively modified proteins, Methods Enzymol 186 (1990), 464-479.
[8] I. Dalle-Donne, R. Rossib, D. Giustarinib, A. Milzania and R. Colomboa, Protein carbonyl groups as biomarkers of oxidative stress, Clin Chim Acta 329 (2003), 23-38.

[9] V. Witko-Sarsat, M. Friedlander, C. Capeillere-Blandin, T. Nguyen-Khoa, A.T. Nguyen, J. Zingraff, P. Jungers and B. Descamps-Latscha, Advanced oxidation protein products as a novel marker of oxidative stress in uremia, Kidney Int 49 (1996), 1304-1313.

[10] U. Çakatay, R. Kayali and H. Uzun, Relation of plasma protein oxidation parameters and paraoxonase activity in the ageing population, Clin Exp Med 8 (2008), 51-57.

[11] D. Bonnefont-Rousselot, P. Therond, J.L. Beaudeux, J. Peynet, A. Legrand and J. Delattre, Aging and oxidative stress. Which potential markers? Ann Biol Clin 59 (2001), 453-459.

[12] B.M. Winklhofer-Roob, A. Meinitzer, M. Maritschnegg, J.M. Roob, G. Khoschsorur, J. Ribalta, I. Sundl, S. Wuga, W. Wonisch, B. Tiran, E. Rock and VITAGE Study Group, Effects of vitamin $\mathrm{E}$ depletion/repletion on biomarkers of oxidative stress in health aging, Ann N Y Acad Sci 1031 (2004), 361-364.

[13] S.I. Rizvi, R. Jha and P.K. Maurya, Erythrocyte plasma membrane redox system in human aging, Rejuvenation Res 9 (2006), 490-474.

[14] G. Cao, S.L. Booth, J.A. Sadowsky and R.L. Prior, Increases in human plasma antioxidant capacity after consumption of controlled diets high in fruit and vegetables, Am J Clin Nutr 68(1998), 1081-1087.

[15] S.I. Rizvi, K.B. Pandey, R. Jha and P.K. Maurya, Ascorbate recycling by erythrocytes during aging in humans, Rejuvenation Res 12 (2009), 3-6.

[16] K.B. Pandey and S.I. Rizvi, Protein oxidation biomarkers in plasma of type 2 diabetic patients, Clin Biochem 43 (2010), 508-511.

[17] I.F.F. Benzie and J.J. Strain, The ferric reducing ability of plasma (FRAP) as a measure of "antioxidant power": The FRAP assay, Anal Biochem 239 (1996), 70-76.

[18] S.I.S. Rattan, Theories of biological aging: Genes, proteins, and free radicals, Free Radic Res 40 (2006), 1230-1238.

[19] M. Bryszewska, I.B. Zavodnik, A. Niekurzale and K. Szosland, Oxidative processes in red blood cells from normal and diabetic individuals, Biochem Mol Biol Int 37 (1995), 345-354.

[20] V. Witko-Sarsat, M. Friedlander, T. Nguyen Khoa, C. Capeillere-Blandin, A.T. Nguyen, S. Canteloup, J.M. Dayer, P. Jungers, T. Drueke and B. Descamps-Latscha, Advanced oxidation protein products as novel mediators of inflammation and monocyte activation in chronic renal failure, J Immunol 161 (1998), 2524-2532.

[21] S.I. Rizvi and P.K. Maurya, L-cysteine influx in erythrocytes as a function of human age, Rejuvenation Res 11 (2008), 661665.

[22] K.B. Pandey and S.I. Rizvi, Markers of oxidative stress in erythrocytes and plasma during aging in humans, Oxid Med Cell Longev 3 (2010), 2-12.

[23] M. Iciek, G. Chwatko, E. Lorenc-Koci, E. Bald and L. Włodek, Plasma levels of total, free and protein bound thiols as well as sulfane sulfur in different age groups of rats, Acta Biochim Pol 51 (2004), 815-824.

[24] A.F. Hühmer, R.G. Biringer, H. Amato, A.N. Fonteh and M.G. Harrington, Protein analysis in human cerebrospinal fluid: Physiological aspects, current progress and future challenges, Dis Markers 22 (2006), 3-26.

[25] O. Gornik and G. Lauc, Glycosylation of serum proteins in inflammatory diseases, Dis Markers 25 (2009), 267-278. 


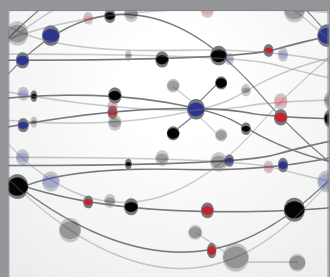

The Scientific World Journal
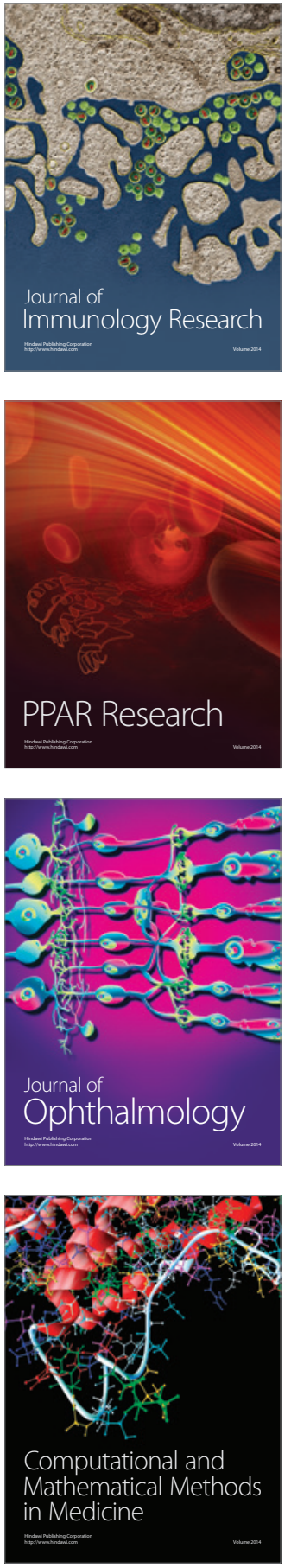

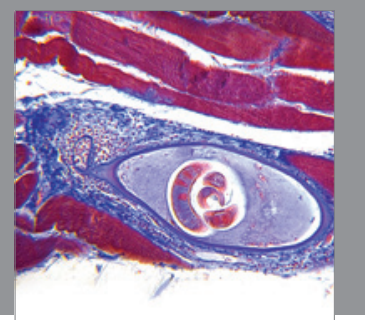

Gastroenterology

Research and Practice
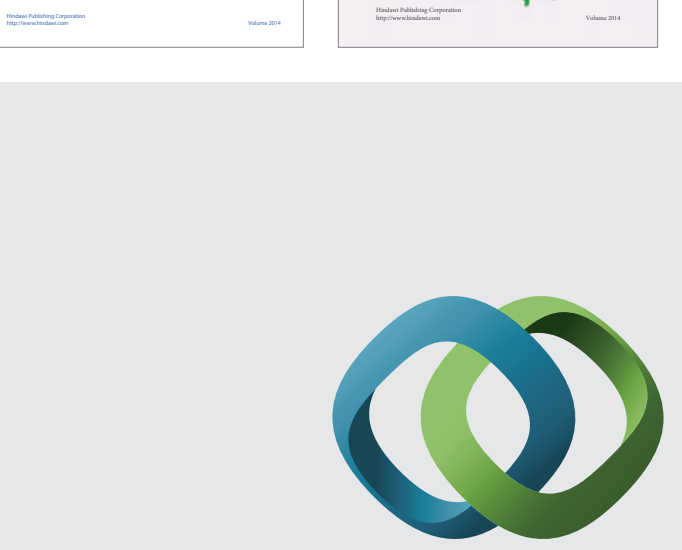

\section{Hindawi}

Submit your manuscripts at

http://www.hindawi.com
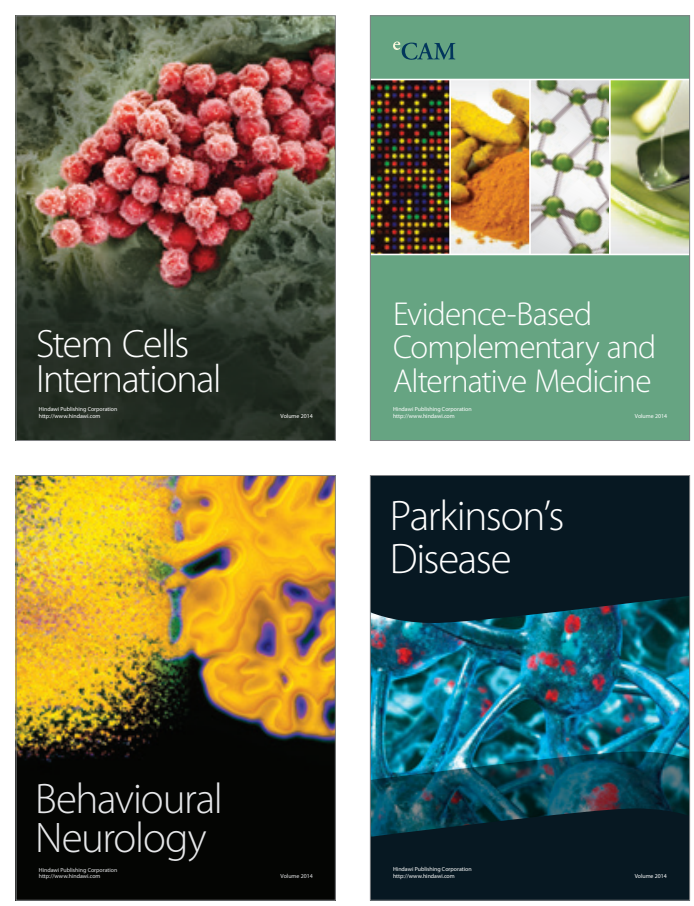

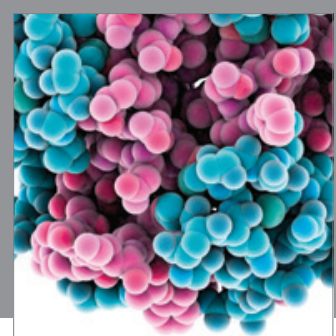

Journal of
Diabetes Research

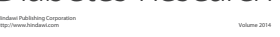

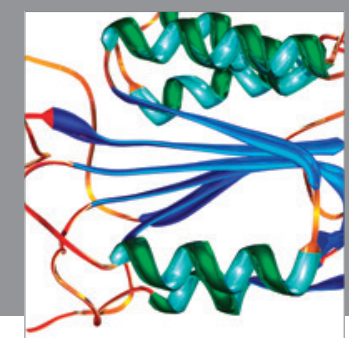

Disease Markers
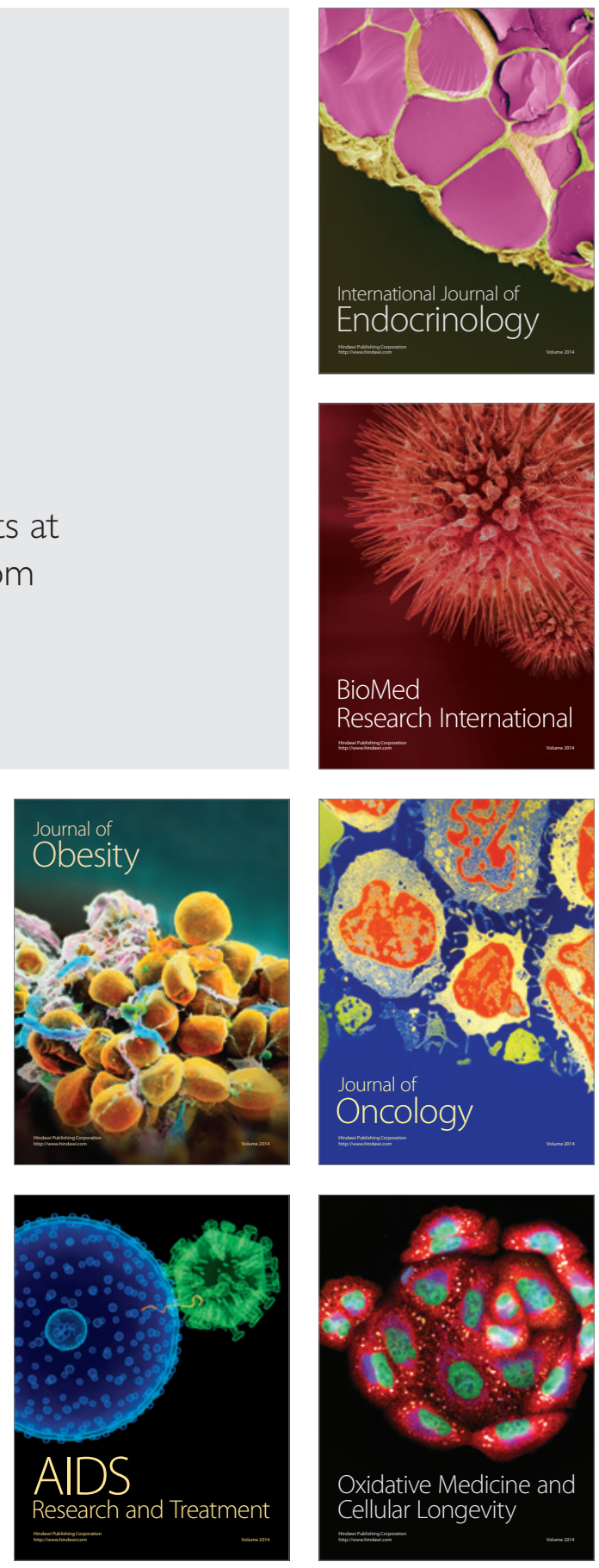